\title{
Trichodinids (Ciliophora: Peritrichida) of Mugil platanus (Mugiliformes: Mugilidae) and Micropogonias furnieri (Perciformes: Sciaenidae) from Samborombón Bay, Argentina, with the description of a new species
}

\author{
Paula S. Marcotegui and Sergio R. Martorelli
}

Centro de Estudios Parasitológicos y de Vectores (CEPAVE), Centro Científico Tecnológico - La Plata, Consejo Nacional de Investigaciones Científicas y Técnicas, Universidad Nacional de La Plata (CCT-La Plata, CONICET, UNLP), Argentina

\begin{abstract}
During surveys of parasites of the whitemouth croaker Micropogonias furnieri (Desmarest) and the mullet Mugil platanus Günther from Samborombón Bay, Argentina, Trichodina puytoraci, T. lepsii, T. jadranica, T. murmanica, Diparitella simplex and Trichodina scalensis sp. n. were morphologically studied. Taxonomic and morphometric data for these trichodinids based on dry silver nitrate-impregnated specimens are presented. This study is the first formal report of these trichodinids from the southwest Atlantic Ocean, and the description of a new species from M. platanus.
\end{abstract}

Key words: Ciliophora, Trichodina, Dipartiella, fish parasites, gill parasites, Southwest Atlantic

In marine and brackish-waters of Argentina, trichodinid ciliophorans remain a poorly studied group. Several authors reported Trichodina sp. from Argentina, but formal descriptions were not made (Cremonte and Figueras 2004, Cremonte et al. 2005). The only species formally described from Southwest Atlantic Ocean Argentinean waters is Trichodina marplatensis Martorelli, Marcotegui et Alda, 2008, found in the ctenophore Mnemiopsis mccradyi (Mayer) (Martorelli et al. 2008).

Samborombón Bay is a bay in the Atlantic Ocean at the outlet of the Río de la Plata. With its lengths of $135 \mathrm{~km}$ it is the biggest mixohaline wetland in Argentina, declared a Ramsar Site in 1997. It is an important nursery area for freshwater, marine, and brackish water fishes, including the two species examined for parasites in the present study. The whitemouth croaker Micropogonias furnieri (Desmarest) and the mullet Mugil platanus Günther have high economical value for the Argentine fishing fleets. Mugil platanus is also commercially exploited by inshore fisheries in Brazil and Argentina.

The aim of this paper is to report five species of trichodinids from mixohaline M. furnieri and M. platanus, and to describe a new species from $M$. platanus collected in the Salado River from Samborombón Bay (Buenos Aires Province, Argentina). Furthermore, the present communication reports on the morphology based on silver nitrate-impregnated preparations and provides data on the prevalence of these species.

\section{MATERIALS AND METHODS}

Fish were collected from coastal areas of Samborombón Bay (Buenos Aires Province, Argentina) $\left(38^{\circ} 00^{\prime} \mathrm{S}\right.$ and $57^{\circ} 33^{\prime} \mathrm{W}$ ) between April 2006 and December 2007. A total of 150 specimens of M. furnieri and 100 specimens of M. platanus were examined. Skin and excised gills from freshly killed fish were examined under a dissecting microscope. Fresh skin and gill smears were made from the hosts. Smears with trichodinids were air dried and Foissner's modification of Klein's dry silver nitrate technique (Foissner 1992) was used to impregnate the specimens to study the adhesive disc and its elements. The sequence and method of the description of denticle elements follow the recommendations of Van As and Basson (1992). Haematoxylin stain was used to reveal nuclear apparatus. Additionally, live specimens, stained with methylene blue, were also used for nuclear observations and details of infraciliature. Examinations of prepared slides were made with a microscope and drawings were made with the help of a camera lucida. The photomicrographs were made with a microscope at $\times 100$ magnification.

The description of each species is based on 20 stained and mounted specimens. All measurements are presented in micrometres; minimum and maximum values are given, followed in parentheses by the arithmetic mean and standard deviation. In case of number of denticles and radial pins per denticle, maximum and minimum are given, followed in parentheses by the mode. The span of the denticle was measured from the tip of blade to the tip of the ray. Cell diameter was measured as the adhesive disc plus border membrane. The type and voucher materials have been deposited in the Museo de La Plata, Argentina, Invertebrate Zoology, Protist Collection (MLP, Coll. Nos. MLP56 to MLP61). 


\section{RESULTS}

\section{Trichodina puytoraci Lom, 1962}

Figs. 1A, 3A

Description. Cell diameter 52.8-75.6 (61.7 \pm 6.1$)$. Centre of disc clear with granules. Blade broad, sickleshaped. Ray well developed, smooth, thin and delicate, almost straight, slanted slightly in anterior direction with ray tapering gradually to rounded point. Macronucleus U-shaped; external diameter 38.5-48.8. For other morphological data on this and other species see Table 1.

H o s t: Mugil platanus Günther, 1880 (Mugiliformes: Mugilidae).

L o c a lit y: Samborombón Bay, Argentina, $38^{\circ} 00^{\prime} \mathrm{S}, 57^{\circ} 33^{\prime} \mathrm{W}$.

Site of infection: Gills.

Prevale n c e : $26 \%$ (26 fish infected / 100 fish examined).

Voucher specimens: MLP56.

Remarks. On the analysis of the morphology and morphometric data, the present species was identified as T. puytoraci Lom, 1962. However, the present population is larger in size than the forms recorded from the mullets Liza aurata (syn. Mugil auratus) (Lom 1962, Özer and Öztürk 2004) and Liza saliens (syn. Mugil saliens) (Lom 1962). Ranzani-Paiva and Silva-Souza (2004) reported Trichodina sp. from M. platanus, but a formal description was not made. This is the first report of T. puytoraci from South America, and a new host record for this species.

\section{Trichodina lepsii Lom, 1962}

Figs. 1B, C, 3B

Description. Cell diameter 28.2-40.8 (35.6 \pm 3.6$)$. Blade broad, almost rectangular. Blade apophysis prominent in some specimens. Ray well developed, straight line directed to the axis $y+1$. Ray apophysis present in some specimens. Macronucleus U-shaped; external diameter $14.9-21.6(18.1 \pm 2.1)$.

H o st: Mugil platanus Günther, 1880 (Mugiliformes: Mugilidae).

L o c a lity: Samborombón Bay, Argentina, $38^{\circ} 00^{\prime} \mathrm{S}, 57^{\circ} 33^{\prime} \mathrm{W}$. Site of infection: Gills.

Prevalence : $26 \%$ (26 fish infected / 100 fish examined). Voucher specimens: MLP57.

Remarks. The morphology and general dimensions of the present species fall within the size ranges given by other authors (Lom 1962, Özer and Öztürk 2004) for T. lepsii. Nevertheless, the specimens observed in this study are slightly larger than those reported previously. Some young specimens show more delicate and more curved rays in contrast with adult specimens. This is the first report of this species from South America, and a new host record.

\section{Trichodina jadranica Raabe, 1958}

Figs. 1D, 3C

Description. Cell diameter 39.2-42.8 (40.6 \pm 1.2 ). Centre of disc clear, with small dark granules. Blade broad, sickle-shaped. Ray apophysis present. Ray slightly curved in posterior direction. Macronucleus U-shaped; external diameter $26.4-43.2(34.7 \pm 5.3)$.

Host: Mugil platanus Günther, 1880 (Mugiliformes: Mugilidae).

L o c a lity: Samborombón Bay, Argentina, $38^{\circ} 00^{\prime} \mathrm{S}, 57^{\circ} 33^{\prime} \mathrm{W}$. Site of infection: Gills.

Prevalence: $26 \%$ (26 fish infected / 100 fish examined).

Voucher specimens: MLP58.

Remarks. Trichodina jadranica has a wide geographical and host distribution, occurring on the gills and skin of marine, brackish-water and freshwater fishes (Arthur and Lom 1984, Dobberstein and Palm 2000, Xu et al. 2001). The morphology of the silver nitrate-impregnated adhesive disk of our specimens from $M$. platanus agrees with those given by previous authors (Lom 1970, Arthur and Lom 1984, Xu et al. 2001). This study is the first report of T. jadranica from Southwest Atlantic Ocean.

Trichodina scalensis sp. $\mathrm{n}$.

Figs. 2 A-C, 3D

Description. Large mixohaline trichodinid. Body cupshaped; cell diameter 39.7-52.4 (46.2 \pm 4.3$)$. Diameter of adhesive disc 34.7-46.2 (41.2 \pm 3.7$)$. Centre of disc with texture similar to rest of adhesive disc. Border membrane 2.6-4.2 $(3.2 \pm 0.4)$ in width. Diameter of denticulated ring 21.4-33.0 (27.8 \pm 3.2$)$. Number of denticles 25-30 (25). Number of radial pins per denticle 5-7 (6). Span of denticle 7.4-9.8 (8.4 \pm 0.6$)$. Length of denticle 5.6-6.6 $(6.3 \pm 0.3)$. Blade broad, 2.8-4.0 $(3.4 \pm 0.3)$ in length, filling most of space between Y-axes. Anterior blade surface rounded, not extending to $\mathrm{y}+1$ axis. Distal blade surface slightly rounded, higher than tangent point. Posterior blade surface very shallow. Apex of blade not prominent. Apophysis of blade not visible. Blade connection broad with posterior projection sometimes prominent. Central part robust, with rounded point fitting tightly into preceding denticle, almost extending about half way to Y-1 axis. Shape of central part above and below X-axis nearly similar. Width of central part 2.0-3.0 (2.4 \pm 0.3$)$. Ray connection robust. Ray well developed, thick with bluntly rounded ends, length 2.5-4.1 (3.0 \pm 0.45$)$, slightly curved in posterior direction, not tapering to the end. Ray apophysis not present. Ratio of denticle above and below $\mathrm{X}$-axis $0.4-0.7: 1$. Adoral ciliary spiral turns c $360^{\circ}-400^{\circ}$ around peristomial disc.

Type host: Mugil platanus Günther, 1880 (Mugiliformes: Mugilidae)

Type locality: Samborombón Bay, Argentina, $38^{\circ} 00^{\prime} \mathrm{S}$, $57^{\circ} 33^{\prime} \mathrm{W}$.

Site of infection: Skin

Prevale nce : $2 \%$ (2 fish infected out of 100 fish examined).

Type specimens: MLP59.

Ety mology: This species is named after the localisation on the host skin (scales) 

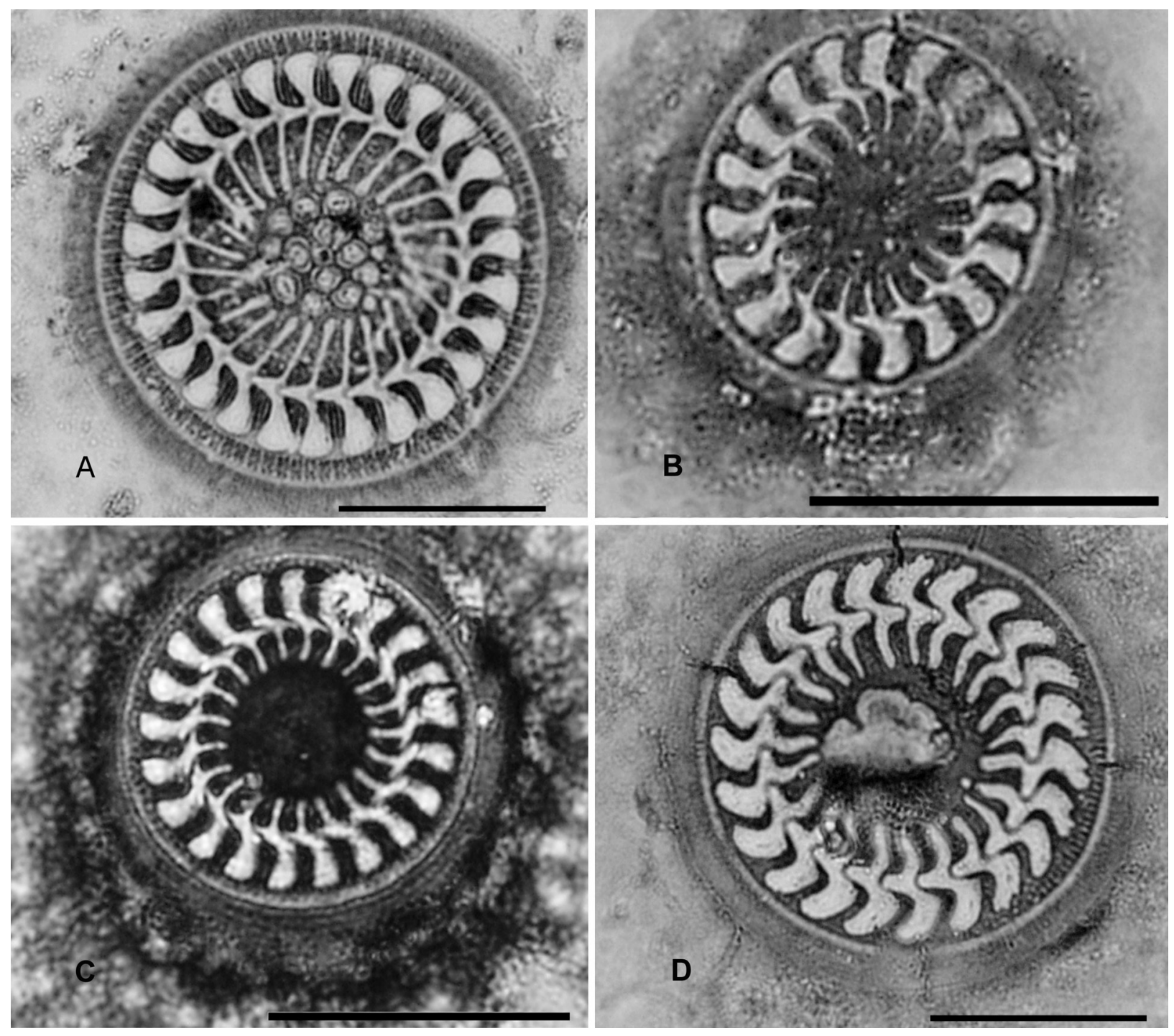

Fig. 1. Photomicrographs of silver nitrate-impregnated adhesive discs of trichodinids from estuarine fishes of Samborombón Bay. A - Trichodina puytoraci from Mugil platanus; B - Young specimen of Trichodina lepsii from M. platanus; C - Adult specimen of T. lepsii from M. platanus; D - Trichodina jadranica from M. platanus. Scale bars $=20 \mu \mathrm{m}$.

Remarks. The new species resembles Trichodina frequentis Shtein, 1979 in terms of its denticle shape. However, T. scalensis differs from T. frequentis by having smaller and slightly curved rays (straight in T. frequentis) smaller ratio of length of ray to blade $(0.4-0.7: 1$ vs. $1.1-$ 1.3:1), as well as larger central part width (vs. delicate).

Trichodina murmanica Poljansky, 1955

Figs. 2 D, E, 3E

Description. Cell diameter 44.0-57.0 (50.4 \pm 4.4$)$. Centre of disc clear with dark granules; in young specimens centre with clear granules. Blade broad, clubshaped. Ray well developed, slightly curved posteriorly. Macronucleus C-shaped; external diameter 23.2-35.7 $(28.0 \pm 4.0)$.
Host: Micropogonias furnieri (Desmarest, 1823) (Perciformes: Sciaenidae).

L o c a lity: Samborombón Bay, Argentina, $38^{\circ} 00^{\prime} \mathrm{S}, 57^{\circ} 33^{\prime} \mathrm{W}$. Site of infection: Gills.

Prevalence : $34 \%$ (51 fish infected / 150 fish examined). Voucher specimens: MLP60.

Remarks. The denticle shape and body size of this species from the present study correspond well with $T$. murmanica described by Shtein (1976) from the White Sea and by other authors previously. According to Poynton and Lom (1989) the most distinctive feature of T. murmanica is the clear centre of the adhesive disc in silver nitrate-impregnated specimens, which contains usually dark granules, and denticles of young specimens showing 

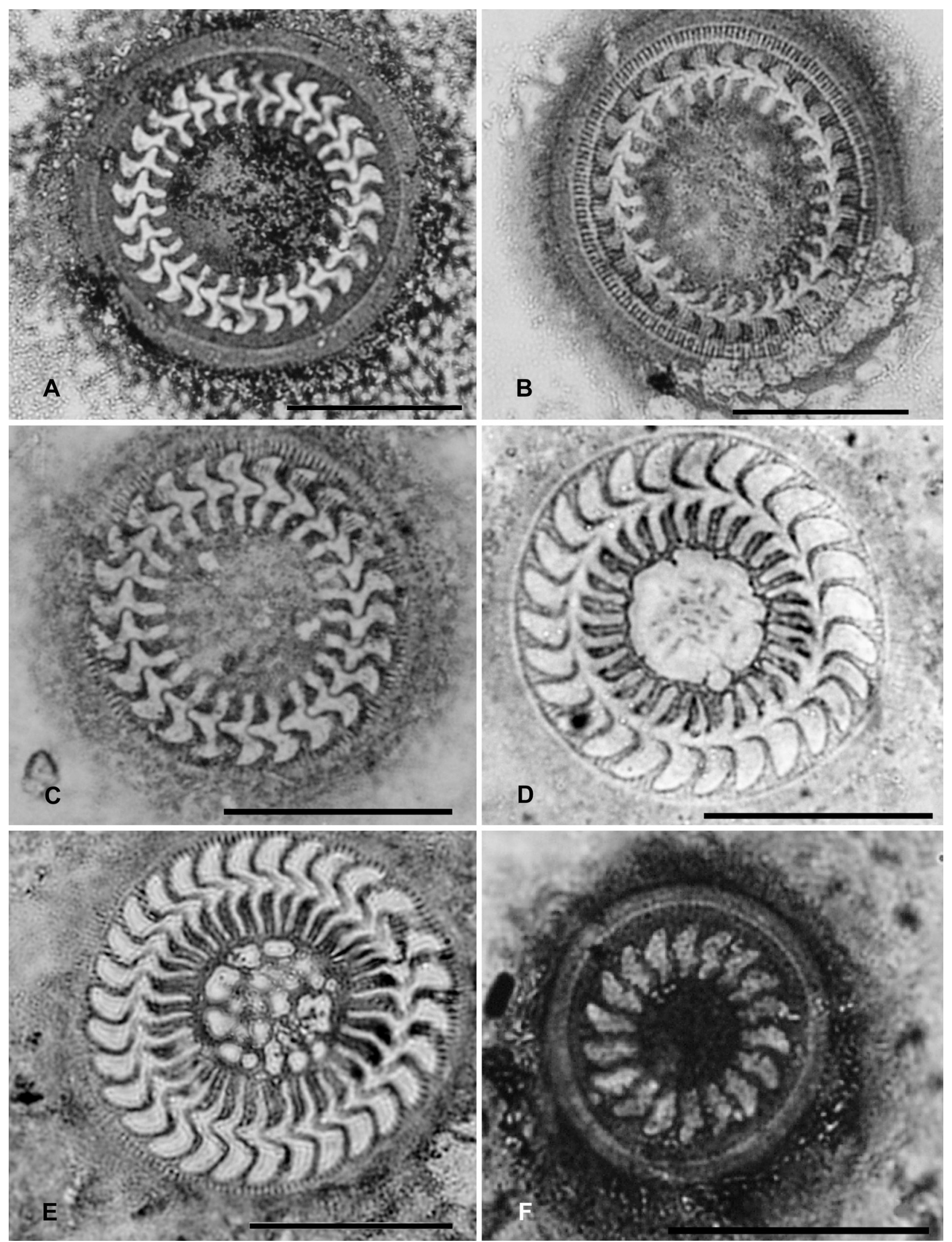

Fig. 2. Photomicrographs of silver nitrate-impregnated adhesive discs of trichodinids from estuarine fishes of Samborombón Bay. A-C - Trichodina scalensis sp. n. from Mugil platanus; D - Trichodina murmanica from Micropogonias furnieri; $\mathbf{E}$ - Young specimen of T. murmanica from M. furnieri; $\mathbf{F}$ - Dipartiella simplex from M. furnieri. Scale bars $=20 \mu \mathrm{m}$. 

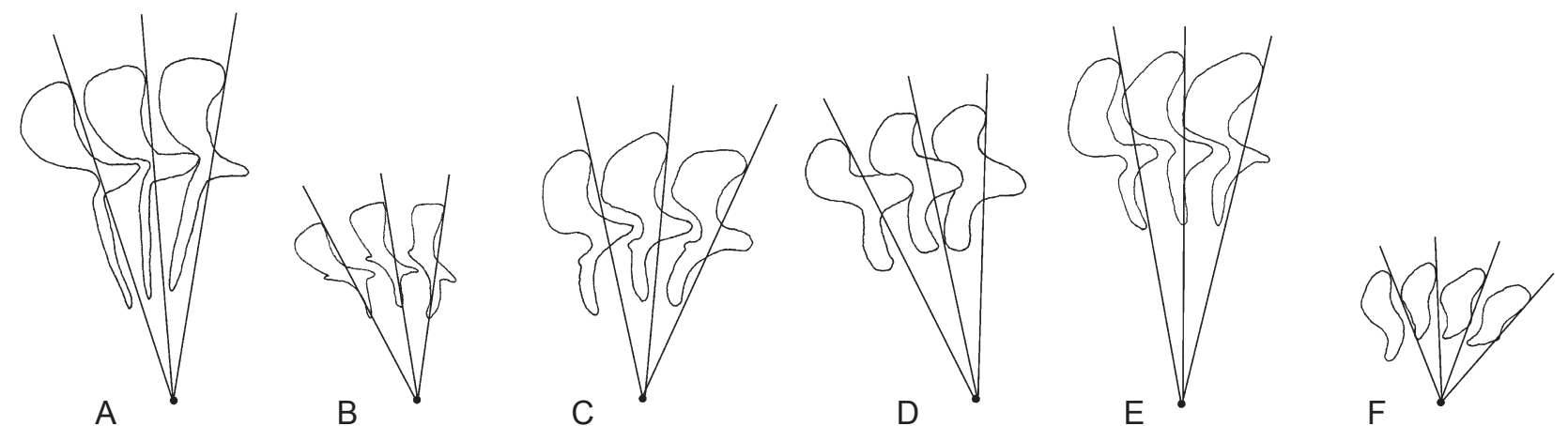

Fig. 3. Diagrammatic drawings of denticles of trichodinids. A - Trichodina puytoraci from Mugil platanus; B - T. lepsii from M. platanus; $\mathbf{C}-$ T. jadranica from M. platanus; $\mathbf{D}-$ T. scalensis sp. n. from skin of M. platanus; $\mathbf{E}-$ T. murmanica from Micropogonias furnieri; $\mathbf{F}$ - Dipartiella simplex from M. furnieri.

some morphologic variations with adults individuals. $\mathrm{Xu}$ et al. (1999) found the centre zone with several clear granules in young individuals during morphogenesis. In our materials we observed this features in some young specimens. Trichodina murmanica has been reported from many coastal fishes and it is widely distributed (Lom and Dyková 1992). This is the first report from South America and also a new host record.

\section{Dipartiella simplex Raabe, 1959}

Figs. 2F, 3F

Description. Cell diameter 23.2-30.8 (26.3 \pm 2.2$)$. Centre of disc similar to rest of adhesive disc. Width and shape of denticle very variable. Blade narrow with sharply tapered outer edges or wide with distal ends rounded. Macronucleus usually horse-shoe-shaped with extensive ends, external diameter 13.6-18.9 (15.5 \pm 1.7$)$.
Host: Micropogonias furnieri (Desmarest, 1823) (Perciformes: Sciaenidae).

L o c a lity: Samborombón Bay, Argentina, $38^{\circ} 00^{\prime} \mathrm{S}, 57^{\circ} 33^{\prime} \mathrm{W}$. Site of infection: Gills.

Prevalence : 34\% (51 fish infected / 150 fish examined). Voucher specimens: MLP61.

Remarks. Dipartiella simplex can be easily recognised by the structure of the denticle, as well as that of the nuclear apparatus. Moreover, our morphometric data agree with the original description. This is the first record of Dipartiella from the Southwest Atlantic Ocean, and also a new host record.

Acknowledgements. This work was funded by a fellowship grant from Consejo Nacional de Investigaciones Científicas y Tecnológicas (CONICET) to P.S. Marcotegui, and a research grant from La Plata National University (UNLP: N504) to S.R. Martorelli.

Table 1. Morphometric data $(\mathrm{n}=20)$ for Trichodina puytoraci Lom, 1960, T. lepsii Lom, 1962, T. jadranica Raabe, 1958, T. murmanica Poljansky, 1955 and Dipartiella simplex Raabe, 1959 from the gills of Mugil platanus and Micropogonias furnieri from Samborombón Bay, Buenos Aires Province, Argentina. Minimum and maximum values are given, followed in parentheses by the arithmetic mean and standard deviation (measurements in $\mu \mathrm{m}$ ). In case of number of denticles and radial pins per denticle, maximum and minimum are given, followed in parentheses by the mode.

\begin{tabular}{|c|c|c|c|c|c|}
\hline Species & T. puytoraci & T. lepsii & T. jadranica & T. murmanica & D. simplex \\
\hline Host & M. platanus & M. platanus & M. platanus & M. furnieri & M. furnieri \\
\hline Adhesive disc diameter & $48.4-64.4(57.1 \pm 4.7)$ & $20.6-36.6(30.9 \pm 4.2)$ & $33.2-37.6(34.4 \pm 1.3)$ & $36.6-52.4(43.16 \pm 5.0)$ & $18.6-26.2(21.6 \pm 2.2)$ \\
\hline Border membrane width & $3.0-5.1(3.9 \pm 0.7)$ & $1.8-3.3(2.6 \pm 0.4)$ & $3-4.8(3.64 \pm 0.52)$ & $2.0-5.6(4.3 \pm 1.1)$ & $1.6-2.4(2.1 \pm 0.3)$ \\
\hline Diameter of denticulated ring & $28.5-39.9(34.1 \pm 3.4)$ & $12.2-21.7(17.9 \pm 2.5)$ & $18.4-21.8(20.5 \pm 1.3)$ & $24.0-35.8(28.3 \pm 3.3)$ & $10.4-16.0(13.0 \pm 1.7)$ \\
\hline Denticle number & $25-29(27)$ & $18-25(21)$ & $21(18-25)$ & $18-25(21)$ & $16-18(17)$ \\
\hline Radial pins per denticle & $5-8(7)$ & $3-5(3-5)$ & $5(3-5)$ & $3-5(5)$ & $5-6(5)$ \\
\hline Denticle span & $14.9-18.4(16.4 \pm 1.2)$ & $4.3-11.9(8.3 \pm 1.6)$ & $5.9-10.5(9.6 \pm 1.4)$ & $9.2-14.4(12.2 \pm 1.5)$ & $4.8-5.6(5.1 \pm 0.3)$ \\
\hline Denticle length & $7.6-11.2(9.2 \pm 1.2)$ & $3.6-6.0(4.9 \pm 0.7)$ & $5.2-6.8(6.3 \pm 0.5)$ & $3.2-7.6(5.5 \pm 1.5)$ & $1.8-3.2(2.4 \pm 0.4)$ \\
\hline Blade length & $5.1-8.0(6.4 \pm 0.7)$ & $3.0-4.9(4.2 \pm 0.5)$ & $4-4.6(4.3 \pm 0.2)$ & $4.0-7.6(5.8 \pm 1.0)$ & $1.6-2.8(2.1 \pm 0.4)$ \\
\hline Central part width & $2.5-3.9(3.2 \pm 0.4)$ & $1.4-2.2(1.8 \pm 0.2)$ & $2.5-3.5(2.9 \pm 0.4)$ & $2.8-4.8(5.5 \pm 4.9)$ & $1-2(1.4 \pm 0.3)$ \\
\hline Ray length & $4.9-9.0(7.3 \pm 0.9)$ & $2.5-3.7(2.9 \pm 0.3)$ & $2.4-4.0(3.3 \pm 0.4)$ & $3.2-7.7(4.8 \pm 1.2)$ & $1-2.4(1.3 \pm 0.5)$ \\
\hline
\end{tabular}




\section{REFERENCES}

Arthur J.R., Lom J. 1984: Some trichodinid ciliates (Protozoa: Peritrichida) from Cuban fishes, with a description of Trichodina cubanensis $\mathrm{n}$. sp. from the skin of Cichlasoma tetracantha. Trans. Am. Microsc. Soc. 103: 172-184.

Cremonte F., Figueras A. 2004: Parasites as possible cause of mass mortalities of the presently critically endangered clam $\mathrm{Me}$ sodesma mactroides on the Southwest Atlantic coast. Bull. Eur. Assoc. Fish Pathol. 24: 166-171.

Cremonte F., Figueras A., Burreson E.M. 2005: A histopathological survey of some commercially exploited bivalve molluscs in northern Patagonia, Argentina. Aquaculture 249: 23-33.

Dobberstein R.C., Palm H.W. 2000: Trichodinid ciliates (Peritrichia: Trichodinidae) from the Bay of Kiel, with description of Trichodina claviformis sp. n. Folia Parasitol. 47: 81-90.

FoIssner W. 1992: The dry silver nitrate method. In: J.J. Lee and A.T. Soldo (Eds.), Protocols in Protozoology. Allen Press, Kansas, C11.1-C11.3.

Lom J. 1962: Trichodinid ciliates from fishes of the Rumanian Black Sea coast. Parasitology 52: 49-61.

Lom J. 1970: Trichodinid ciliates (Peritrichida: Urceolariidae) from some marine fishes. Folia Parasitol. 17: 113-125.

Lom J., Dyková I. 1992: Protozoan Parasites of Fishes. Elsevier, New York, 315 pp.

Martorelli S., Marcotegui P., Alda M. 2008: Trichodina marplatensis sp. n. (Ciliophora: Trichodinidae) from Combjelly,

Received 11 February 2009
Mnemiopsis mccradyi (Mayer, 1900) in Argentine Sea. Acta Protozool. 47: 257-261.

ÖZer A., ÖzTÜRK T. 2004: Trichodina puytoraci Lom, 1962 and Trichodina lepsii Lom, 1962 (Peritrichida: Ciliophora) infestations on mugilids caught at the Black Sea Coast of Sinop in Turkey. Turk. J. Zool. 28: 179-182.

Poynton S.L., Lom J. 1989: Some ectoparasitic trichodinids from Atlantic cod, Gadus morhua L., with a description of Trichodina cooperi n. sp. Can. J. Zool. 67: 1793-1800.

Ranzani-Paiva M.J., Silva-Souza A.T. 2004: Co-infestation of gills by different parasite groups in the mullet, Mugil platanus Günther, 1880 (Osteichthyes, Mugilidae): effects on relative condition factor. Braz. J. Biol. 64: 677-682.

Shtein G.A. 1976: Parasitic ciliates (Peritrichia: Urceolariidae) of fishes of the White Sea. Acta Protozool. 15: 447-468.

VAN As J.G., BAsson L. 1992: Trichodinid ectoparasites (Ciliophora: Peritrichida) of freshwater fishes of the Zambesi River System, with a reappraisal of host specificity. Syst. Parasitol. 22: 81-109.

Xu K., Song W., Warren A. 1999: Trichodinid ectoparasites (Ciliophora: Peritrichida) from the gills of cultured marine fishes in China, with the description of Trichodinella lomi n. sp. Syst. Parasitol. 42: 219-227.

Xu K., Song W., Warren A., Choi J.K. 2001: Trichodinid ectoparasites of some marine fishes from coastal regions of the Yellow and Bohai Sea. Syst. Parasitol. 50: 69-79.

Accepted 10 July 2009 